\title{
PENGARUH RISK TAKING DAN FREE CASH FLOW TERHADAP PEMBAGIAN DEVIDEN \\ (STUDI EMPIRIS PADA BANK UMUM YANG TERDAFTAR DI BURSA EFEK INDONESIA TAHUN 2014-2016)
}

\author{
Indrayani ${ }^{1}$, Aprina ${ }^{2}$ \\ ${ }^{1,2}$ Prodi Akuntansi Fakultas Ekonomi dan Bisnis Universitas Malikussaleh Lhokseumawe \\ Indrayani@unimal.ac.id
}

\begin{abstract}
Absract: This study aimed to determine the effect of Risk Taking and Free Cash Flow on Dividend Payout. The number of samples used in this study was 39 observations at Commercial Banks listed on the Indonesia Stock Exchange (BEI) in 2014-2016. The sample was taken by using purposive sampling technique. The method of data analysis used in this research was multiple linear regression analysis. The result of research partially showed that Risk taking had a negative and significant effect on dividend payout and Free Cash Flow had a positive and significant effect on dividend payout. Simultaneously, Risk Taking and Free Cash Flow had a significant effect on dividend payout.
\end{abstract}

Keywords: Dividend Payout, Risk Taking, Free Cash Flow.

\section{PENDAHULUAN}

Bank Umum menurut Undang-Undang RI Nomor 7 tahun 1992 tentang perbankan sebagaimana diperbaharui dengan UU nomor 10 tahun 1998, merupakan bank yang melaksanakan kegiatan usaha secara konvensional berdasarkan prinsip syariah, yang dalam kegiatannya memberikan jasa dalam lalu lintas pembayaran. Peranan bank sangat besar dalam mendorong pertumbuhan ekonomi suatu Negara. Kondisi persaingan di dunia perbankan yang semakin ketat menyebabkan setiap bank harus berupaya memperbaiki kinerja keuangan agar lebih baik dari bank lain. Semakin baik kinerja keuangan suatu bank maka akan menambah kepercayaan investor untuk menanamkan modalnya di bank tersebut.

Pernyataan Standar Akuntansi Keuangan No.1 (Revisi 2013), tujuan umum dari laporan keuangan adalah untuk memberikan informasi mengenai posisi keuangan, kinerja keuangan, dan arus kas entitas yang bermanfaat bagi sebagian besar kalangan pengguna dalam pembuatan keputusan ekonomi. Salah satu pengguna laporan keuangan dari pihak eksternal adalah investor. Informasi dalam laporan keuangan dapat dipakai oleh para investor untuk melakukan pengambilan keputusan investasi yang tepat.

Keputusan investasi yang tepat tersebut diharapkan dapat memberikan keuntungan bagi investor di masa depan. Keuntungan yang bisa didapatkan investor atas investasi saham yang dilakukan pada

pembagian deviden yang dilakukan oleh bank umum tahun 2014-2016. perusahaan dapat berupa capital gain dan dividen. Capital gain artinya terdapat selisih untung atas hasil penjualan saham dibanding saat pembelian saham, sedangkan deviden merupakan bagian keuntungan perusahaan yang dibagikan kepada investor.

Bagi investor jangka panjang, dividen merupakan hal yang lebih menarik dibanding capital gain. Alasan utama lebih disukai dividen adalah adanya kepastian, sedangkan mengharapkan kenaikan harga saham adalah sesuatu yang belum pasti. Oleh karena itu, dividen dianggap menawarkan kepastian yang lebih baik daripada capital gain.

Kebijakan dividen adalah keputusan apakah laba yang diperoleh perusahaan akan dibagikan kepada pemegang saham sebagai dividen atau akan ditahan dalam bentuk laba ditahan guna pembiayaan investasi di masa mendatang (Mulyawan, 2015:253).

Keputusan pembagian deviden kepada pemegang saham sangat bergantung pada keberhasilan dan stabilitas perusahaan dalam menghasilkan keuntungan. Jika kinerja keuangan dalam kondisi baik dan stabil setiap tahunnya. Maka investor akan mendapat keuntungan dari saham yang ia miliki di perusahaan tersebut dalam bentuk deviden, sedangkan jika kinerja keuangan perusahaan sedang dalam konsidi negatif mungkin tidak akan menerima keduanya.

Pembagian dividen yang dilakukan oleh perusahaan kepada investornya dapat diukur dengan Dividend Payout Ratio (DPR). Berikut grafik

Gambar 1

Grafik Data Pembagian Deviden 


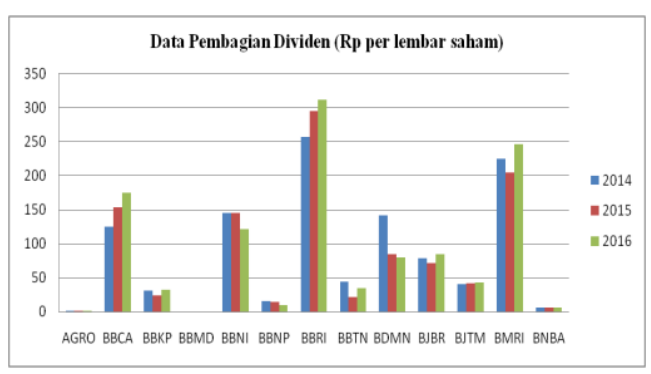

Sumber: Data Sekunder

Berdasarkan grafik diatas, maka dapat disimpulkan bahwa, pembagian deviden yang dilakukan oleh Bank Umum mengalami fluktuasi disetiap tahunnya yaitu dari tahun 2014-2016 yang dapat dilihat dari nilai Dividend Payout Ratio (DPR). Seperti yang kita ketahui bahwa investor cenderung mengharapkan pembayaran deviden yang stabil, karena dapat mengurangi resiko ketidakpastian pada saham yang ditanamkannya. Stabilitas deviden juga akan meningkatkan kepercayaan investor dalam menanamkan modalnya, akan tetapi pada kenyataannya dividen yang akan dibagikan tidak mengindikasikan adanya penerapan kebijakan deviden yang stabil. Pada tahun 2014 tingkat perkembangan rata-rata dividen yaitu sebesar $85,5 \%$, kemudian mengalami penurunan pada tahun 2015 menjadi $63,5 \%$, dan pada tahun 2016 mengalami peningkatan menjadi 88,09\%. Dari sisi investor, deviden merupakan salah satu penyebab timbulnya motivasi investor untuk menanamkan dananya di pasar modal, dan karena informasi yang dimiliki investor di pasar modal sangat terbatas, maka perubahan dividenlah yang akan dijadikan sebagai sinyal untuk mengetahui performance perusahaan.

Pembagian dividen sebagian besar dipengaruhi oleh perilaku investor yang lebih memilih dividen tinggi yang mengakibatkan laba ditahan menjadi rendah. Investor beranggapan bahwa dividen yang diterima saat ini menjadi lebih berharga dibandingkan dengan capital gains yang diperoleh di kemudian hari. Di sisi lain, pihak manajemen menahan kas untuk melunasi hutang atau meningkatkan investasi. Oleh karena itu manajemen perlu membuat kebijakan dividen yang optimal dimana kebijakan tersebut menciptakan keseimbangan di antara dividen saat ini dan pertumbuhan di masa yang akan datang sehingga memaksimumkan nilai perusahaan (Brigham dan Houston, 2001:66).

Kinanti (2015) menyatakan bahwa salah satu yang mempengaruhi kebijakan deviden adalah risk taking. Risk-taking didefinisikan sebagai pengambilan aktivitas yang mengandung ketidakpastian atau resiko untuk meningkatkan keuntungan, dimana aktivitas tersebut mengandung kemungkinan kerugian dalam bentuk harta atau kehilangan keuntungan atau kemampuan ekonomis, yang akan melemahkan permodalan bank. Risk taking dapat diukur dengan menggunakan Z-score untuk masing-asing bank. Hubungan antara risk taking dengan pembayaran deviden di perusahaan non-keuangan dan perusahaan keuangan (bank) akan berbeda, salah satu penyebab perbedaan tersebut disebabkan karena bank merupakan regulated industries. Regulasi yang mengatur industri perbankan yang disikapi berbeda oleh setiap bank. Banyaknya regulasi tersebut juga dapat menciptakan celah bagi industri perbankan untuk melakukan tindakan yang melawan hukum atau etika bisnis (Moral hazard).

Selain itu, free cash flow juga akan mempengaruhi kebijakan deviden. Free cash flow merupakan sisa dari pendanaan seluruh proyek yang menghasilkan net present value (NPV) positif yang didiskontokan pada tingkat biaya modal yang relevan. Apabila perusahaan memiliki free cash flow, perusahaan lebih baik membaginya dalam bentuk pembagian dividen untuk mengurangi kemungkinan dana tersebut diboroskan pada proyek yang tidak menguntungkan.

Free cash flow menunjukkan gambaran bagi investor bahwa dividen yang dibagikan oleh perusahaan tidak sekadar strategi menyiasati pasar dengan maksud meningkatkan nilai perusahaan. Bagi perusahaan yang melakukan pengeluaran modal, free cash flow akan mencerminkan dengan jelas mengenai perusahaan manakah yang masih mempunyai kemampuan di masa depan dan yang tidak (Jensen dalam Ramadhan, 2014).

\section{TINJAUAN PUSTAKA}

\section{Risk Taking}

Kinanti (2015), Risk-taking didefinisikan sebagai aktivitas mengambil risiko untuk memulai sebuah perusahaan atau meningkatkan keuntungan. Dimana risiko didefinisikan sebagai ketidak-pastian yang mengandung kemungkinan kerugian dalam bentuk harta atau kehilangan keuntungan atau kemampuan ekonomis. Kerugian dalam bentuk harta atau kehilangan keuntungan atau kemampuan ekonomis akan melemahkan permodalan bank. Kesulitan permodalan dalam jumlah yang besar dan dalam waktu yang lama dapat meningkatkan potensi default risk bank.

Dalam penelitian ini, default risk yang dimaksud adalah keadaan dimana bank tidak akan dapat melakukan pembayaran yang diminta atas kewajiban utangnya kepada pemberi pinjaman atau tidak mampu mengembalikan simpanan deposan di 
bank. Maka dalam penelitian ini, risk-taking didefinisikan sebagai pengambilan aktivitas yang mengandung ketidakpastian untuk meningkatkan keuntungan di mana aktivitas tersebut mengandung kemungkinan kerugian dalam bentuk harta atau kehilangan keuntungan atau kemampuan ekonomis. Risk-taking dapat diukur dengan menggunakan Zscore untuk masing-masing bank. Z-score merupakan rasio untuk mengukur jarak dari kegagalan (insolvency). Berikut adalah rumus untuk menghitung risk-taking (LnZ).

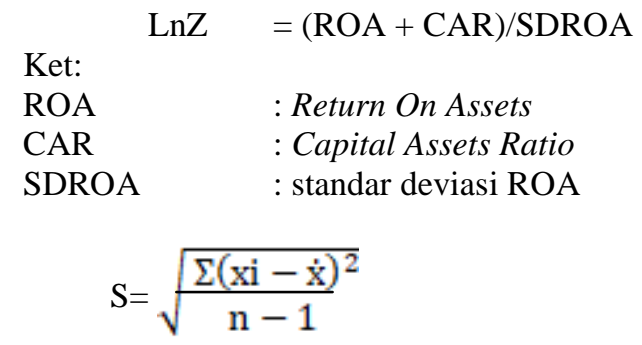

\section{Free Cash Flow}

Prasetio (2015) mengartikan aliran kas bebas atau free cash flow sebagai aliran kas yang tersedia untuk dibagikan kepada para pemegang saham atau pemilik dalam bentuk dividen. Pembagian tersebut dilakukan setelah perusahaan melakukan investasi pada aset tetap (fixed asset) dan modal kerja (working capital) yang diperlukan untuk kelangsungan usahanya. Free cash flow diukur dengan membandingkan nilai bersih kenaikan/penurunan arus kas dari aktivitas operasi perusahaan (cash flow capital operations) dengan total asset. Dengan rumus.

$$
\mathrm{FCF}=\frac{\mathrm{CFO}}{\text { Total Asset }}
$$

Jadi dapat disimpulkan bahwa, Free Cash Flow dipakai oleh manajer untuk menentukan seberapa banyak kas yang dapat dihasilkan oleh perusahaan setelah mempertahankan kapasitas produktif saat ini. Manajemen dapat menggunakan Free Cash Flow untuk menentukan jumlah kas yang akan dipakai untuk pelebaran perusahaan, pembayaran utang, pengumuman dividen, pembelian kembali saham, dan tujuan lainnya.

\section{Pembagian Deviden}

Menurut Rosdini (2005), Dividen merupakan pembayaran dari perusahaan kepada para pemegang saham atas keuntungan yang diperolehnya. Kebijakan dividen adalah kebijakan yang berhubungan dengan pembayaran dividen oleh pihak perusahaan, berupa penentuan besarnya dividen yang akan dibagikan dan besarnya saldo laba yang ditahan untuk kepentingan perusahaan. Dividen merupakan bagian laba perusahaan yang dibagikan kepada pemegang saham berdasarkan jumlah saham yang dimiliki. Pendistribusian dividen akan mengurangi jumlah laba ditahan dan saldo kas yang dimiliki perusahaan.

Pembagian dividen yang dilakukan oleh perusahaan kepada investornya dapat diukur dengan rumus Dividend Payout Ratio (DPR), Dividend Payout Ratio adalah proporsi dividen yang dibagikan untuk pemegang saham dari laba bersih perusahaan (Haryadi, 2014). Adapun dasar perhitungan untuk Dividend Payout Ratio adalah:

\section{Dividend Payout Ratio $=\underline{\text { Dividend per Share }}$ Earning per Share}

\section{Penelitian Terdahulu}

Penelitian yang berhubungan dengan RiskTaking dan Free Cash Flow telah dilakukan oleh beberapa peneliti seperti Kinanti dan I putu (2015) yang berjudul Pengaruh Risk-Taking Terhadap Pembagian Deviden. Penelitian tersebut bertujuan untuk menguji pengaruh Risk-Taking yang diproksikan dengan logaritma natural Z-score terhadap pembagian deviden yang diproksikan dengan devident payout ratio (DPR). Dimana hasilnya yaitu variabel risk-taking berpengaruh negatif signifikan terhadap pembagian dividen. Hal ini berarti semakin tinggi risk-taking yang dimiliki perusahaan semakin rendah dividen yang dibagikan oleh bank. Atau dalam arti lain perusahaan dengan Risk-Taking yang lebih tinggi dimungkinkan melakukan pembagian deviden yang lebih rendah daripada perusahaan dengan RiskTaking yang rendah.

Prasetyo dan Bambang (2015) yang berjudul Pengaruh Profitabilitas, Free Cash Flow, Investment Opportunity Set Terhadap Dividend Payout Ratio. Tujuan penelitian ini adalah untuk menguji profitabilitas, free cash flow dan investment opportunity set berpengaruh signifikan dan positif terhadap devident payout ratio pada perusahaan otomotif yang terdaftar di Bursa Efek Indonesia. Dimana hasilnya Profitabilitas berpengaruh signifikan 
dan positif terhadap dividend payout ratio pada perusahaan otomotif di Bursa Efek Indonesia. Free cash flow berpengaruh signifikan dan positif terhadap dividend payout ratio pada perusahaan otomotif di Bursa Efek Indonesia. Invesment opportunity set berpengaruh signifikan dan positif terhadap dividend payout ratio pada perusahaan otomotif di Bursa Efek Indonesia.

Lucyanda dan Lilyana (2012) yang berjudul Pengaruh Free Cash Flow dan Struktur Kepemilikan Terhadap Dividend Payout Ratio. Penelitian ini bertujuan menguji bagaimana free cash flow dan struktur kepemilikan berpengaruh terhadap devident payout ratio pada perusahaan non-keuangan yang terdaftar di bursa efek indonesia. Dimana hasilnya yaitu variabel free cash flow berpengaruh positif terhadap dividend payout ratio. Persentase kepemilikan institusional berpengaruh negatif terhadap dividend payout ratio. Kepemilikan keluarga dan persentase kepemilikan asing tidak berpengaruh secara signifikan terhadap dividend payout ratio.

\section{METODOLOGI PENELITIAN}

\section{Objek dan Lokasi Penelitian}

Objek dan lokasi dalam penelitian ini adalah Bank Umum yang terdaftar di Bursa Efek Indonesia (BEI) tahun 2014-2016.

\section{Populasi dan sampel}

Populasi dalam penelitian ini adalah seluruh Bank Umum, yaitu ada 43 Bank Umum yang terdaftar di Bursa Efek Indonesia tahun 2014-2016. Dalam penelitian ini, sampel ditentukan dengan menggunakan metode purposive sampling. Metode sampling tersebut membatasi pemilihan sampel berdasarkan kriteria tertentu. Adapun sampel penelitian ini adalah 13 Bank Umum yang terpilih sesuai Kriteria.

\section{Teknik Pengumpulan data}

Jenis data dalam penelitian ini dengan menggunakan data sekunder melalui metode dokumentasi. Metode dokumentasi adalah metode pengumpulan data dengan cara mengumpulkan datadata dokumenter berupa laporan keuangan dari setiap
Bank Umum. Data sekunder adalah data yang diperoleh atau dikumpulkan oleh orang-orang yang melakukan penelitian dari sumber yang telah ada, umumnya berupa bukti, catatan atau laporan historis yang telah di susun dalam arsip. Dalam penelitian ini data yang di gunakan berupa data laporan keuangan dan catatan atas laporan keuangan Bank Umum yang terdaftar di Bursa Efek Indonesia tahun 2014-2016. Sumber data diperoleh melalui publikasi situs resmi Bursa Efek Indonesia (BEI) www. Idx.co.id.

\section{Metode Analisis Data}

Penelitian ini menggunakan pengujian statistik deskriptif dan pengujian hipotesis untuk menganalisa data. Untuk menganalisa data dengan analisis regresi berganda digunakan SPSS. Sebagai prasarat melakukan pengujian regresi berganda, dilakukan uji asumsi klasik untuk memastikan bahwa data penelitian memiliki sebaran data yang normal. Statistik diskriptif merupakan alat statistik yang berfungsi untuk mendeskripsikan atau memberi gambaran terhadap objek yang diteliti melalui data sampel atau populasi sebagaimana adanya, tanpa melakukan analisis dan membuat kesimpulan yang berlaku umum dari data tersebut. Uji asumsi klasik dilakukan untuk mengetahui beberapa penyimpangan yang terjadi pada data yang digunakan untuk penelitian.

Penelitian ini menggunakan regresi linear berganda untuk memperoleh gambaran yang menyeluruh mengenai hubungan antara variabel satu dengan variabel yang lain. Persamaan regresi dalam penelitian ini adalah sebagai berikut:

$$
\mathrm{Y}=\mathrm{a}+\mathrm{b}_{1} \mathrm{X}_{1}+\mathrm{b}_{2} \mathrm{X}_{2}+\mathrm{e}
$$

\section{HASIL PENELITIAN DAN PEMBAHASAN}

\section{Deskriptif Variabel Penelitian}

Analisis Deskriptif ini digunakan untuk memberikan gambaran atau deskripsi mengenai variabel dependen yaitu Pembagian Deviden, serta variabel independen yaitu Risk Taking dan Free Cash Flow pada Bank Umum yang terdaftar di BEI tahun 2014-2016. Deskriptif data variabel yang ada dalam penelitian ini dapat dilihat dalam tabel berikut: 
Tabel 1

\section{Deskriptif Statistik Penelitian}

Descriptive Statistics

\begin{tabular}{|c|c|c|c|c|c|}
\hline & $\mathrm{N}$ & $\begin{array}{l}\text { Minimu } \\
\mathrm{m}\end{array}$ & $\begin{array}{l}\text { Maxi } \\
\text { mum }\end{array}$ & Mean & $\begin{array}{l}\text { Std. } \\
\text { Deviati } \\
\text { on }\end{array}$ \\
\hline LN_Y & 39 & -4.42 & 5.74 & 3.0900 & $\begin{array}{l}2.6154 \\
3\end{array}$ \\
\hline LN_x1 & 39 & 2.13 & 3.31 & 2.7170 & .31039 \\
\hline $\mathrm{X} 2$ & 39 & -.430 & .390 & .03205 & $\begin{array}{l}.12450 \\
1\end{array}$ \\
\hline $\begin{array}{l}\text { Valid N } \\
\text { (listwis } \\
\text { e) }\end{array}$ & 39 & & & & \\
\hline
\end{tabular}

\section{Uji Asumsi Klasik}

\section{Uji Normalitas}

Pengujian normalitas dalam penelitian ini dilakukan menggunakan alat uji Kolmogorov-Smirnov Test dengan nilai residu atas persamaan model regresi yang digunakan dalam penelitian. Hasil uji normalitas dapat dilihat dalam tabel berikut:

\section{Tabel 2}

\section{Hasil Uji Normalitas}

One-Sample Kolmogorov-Smirnov Test

\begin{tabular}{|c|c|c|}
\hline & & $\begin{array}{l}\text { Unstandardized } \\
\text { Residual }\end{array}$ \\
\hline $\mathrm{N}$ & & 39 \\
\hline $\begin{array}{l}\text { Normal } \\
\text { Parameters }\end{array}$ & Mean & .0000000 \\
\hline & $\begin{array}{l}\text { Std. } \\
\text { Deviation }\end{array}$ & 2.26647153 \\
\hline Most Extreme & Absolute & .106 \\
\hline
\end{tabular}

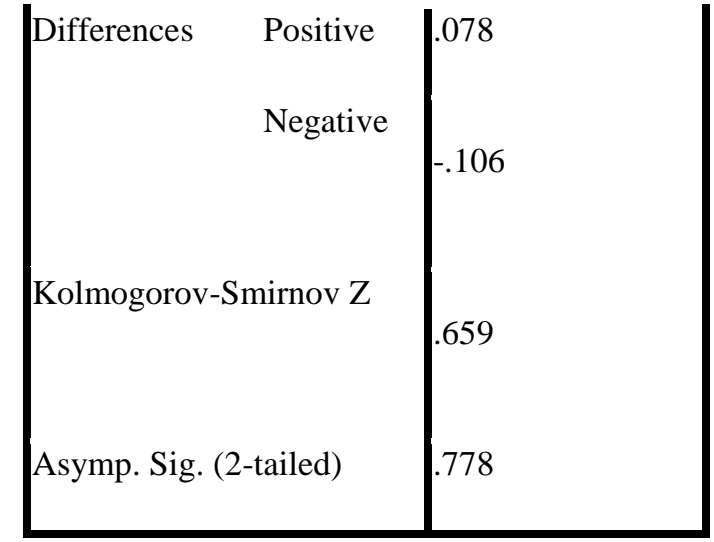

a. Test distribution is Normal

b. Calculate from data

\section{Uji Multikolinearitas}

Uji multikolinieritas adalah situasi adanya korelasi variabel-variabel bebas diantara satu dengan yang lain model regresi berganda harus terbebas dari multikolinieritas untuk satu variabel dependennya. Untuk mendeteksi ada tidaknya multikolinieritas dalam model regresi dapat dilihat dari nilai tolerance dan Variance Inflation Factor (VIF). Hasil pengujian multikolinearitas adalah sebagai berikut

\section{Tabel 3}

\section{Hasil Uji Multikolinieritas}

\section{Coefficients $^{\mathrm{a}}$}

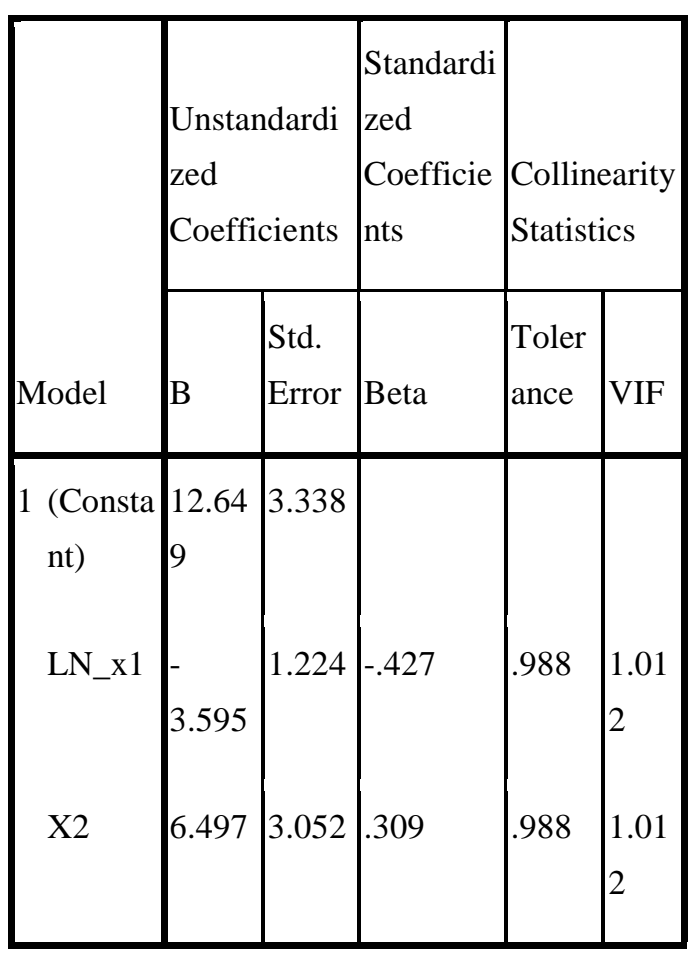

a. Dependent Variable: Ln_Y 


\section{Uji Autokorelasi}

Uji autokorelasi bertujuan untuk menguji apakah model dalam model regresi linier ada korelasi antar pengganggu pada periode sebelumnya. Jika terjadi korelasi maka dinamakan ada problem autokorelasi. Data yang baik adalah regresi yang bebas dari autokorelasi. Pendekatan yang sering digunakan untuk menguji ada tidaknya autokorelasi adalah uji Durbin-Watson (DW). Pengujian autokolerasi dapat dilakukan dengan menghitung Durbin-Watson (d), dengan membandingkan nilai d terhadap dl dan du. Setelah menghitung nilai statistik selanjutnya dibandingkan dengan tabel, dengan tingkat signifikan 5\%.

Tabel 4 Hasil Uji Autokorelasi

\section{Model Summary ${ }^{b}$}

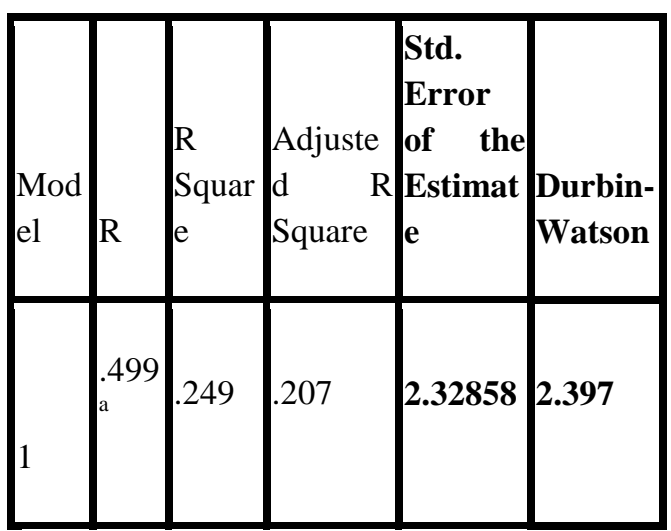

a. Predictors: (Constant), x2, Ln_x1

b. Dependent Variable: Ln_Y

\section{Uji Heteroskedastisitas}

Uji ini bertujuan untuk menguji apakah dalam model regresi terjadi ketidaknyamanan variance dari residual satu pengamatan ke pengamatan yang lain. Jika variance dari residual satu pengamatan ke pengamatan yang lain tetap, maka disebut sebagai homokedastisitas. Hasil pengujian heteroskedastisitas adalah sebagai berikut

\section{Gambar 2}

Hasil Uji Heteroskedastisitas

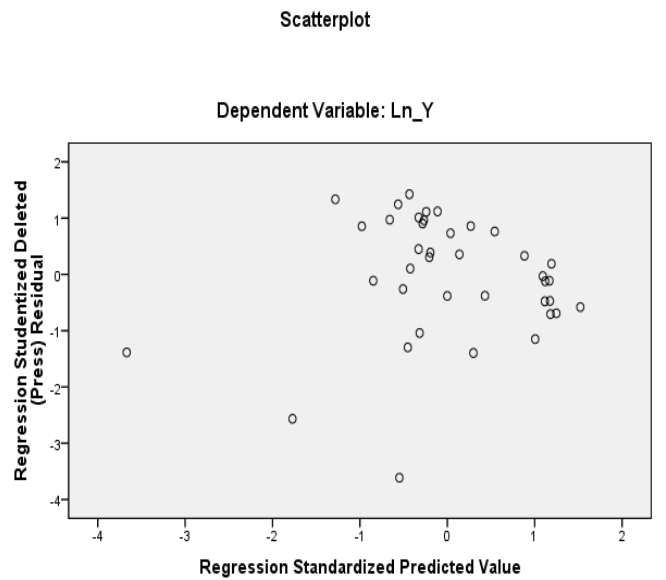

Salah satu cara untuk mengetahui ada tidaknya heteroskedastisitas dalam suatu model regresi linier berganda adalah dengan melihat grafik scatterplot atau nilai prediksi variabel terikat yaitu ZPRED dengan residual error yaitu SRESID. Jika tidak ada pola tertentu dan tidak menyebar diatas dan dibawah angka nol pada sumbu Y, maka tidak terjadi heteroskedastisitas.

Berdasarkan Gambar diatas dapat diketahui bahwa data (titik-titik) menyebar secara merata di atas dan di bawah garis nol, tidak berkumpul di satu tempat, serta tidak membentuk pola tertentu sehingga dapat disimpulkan bahwa pada uji regresi ini tidak terjadi heteroskedastisitas.

\section{Analisis Regresi Linear Berganda}

Secara umum analisis ini digunakan untuk menggambarkan hubungan linear dari beberapa variabel independen (variabel $\mathrm{X}$ ) terhadap variabel dependen (variabel Y). Berdasarkan hasil regresi pada SPSS, maka diperoleh persamaan regresi linear berganda sebagai berikut:

$\mathrm{Y}=12.649-3.595 \mathrm{X} 1+6.497 \mathrm{X} 2+\mathrm{e}$

\section{Uji Hipotesis}

\section{Uji t-statistik (Parsial)}

Uji statistik $\mathrm{t}$ pada dasarnya menunjukkan seberapa jauh pengaruh satu variabel independen secara individual dalam menerangkan variasi variabel dependen (Ghozali,2006). Bila $t_{\text {hitung }}>t_{\text {tabel }}$ dengan tingkat signifikan 5\%, maka dapat disimpulkan bahwa secara parsial variabel independen berpengaruh signifikan terhadap variabel dependen. Jika $t_{\text {hitung }}<$ $\mathrm{t}_{\text {tabel }}$ dengan tingkat signifikan 5\%, maka dapat 
disimpulkan bahwa variabel independen tidak berpengaruh terhadap variabel dependen. Menurut Ghozali (2006) uji ini dilakukan dengan ketentuan sebagai berikut :

$\mathrm{Ha}_{1}$ diterima jika angka signifikansi $<5 \%$

$\mathrm{Ho}_{1}$ ditolak jika angka signifikansi $>5 \%$.

\section{Pengaruh Risk Taking (X1) terhadap Pembagian Deviden}

Nilai $t_{\text {hitung }}$ dari X1 sebesar -2.397 dengan nilai signifikannya adalah 0,006 sementara nilai $t_{\text {tabel }}$ pada $\alpha$ $=0.05$ diperoleh nilai sebesar 2.02809 artinya $t_{\text {hitung }}>$ $\mathrm{t}_{\text {tabel}}$. Maka keputusannya menerima $\mathrm{H}_{1}$, yang artinya secara parsial X1 berpengaruh secara signifikan terhadap Y, tetapi memiliki hubungan yang negatif, Dimana semakin besar risk taking dalam suatu bank, maka semakin kecil pembagian deviden dalam bank tersebut, dan begitu juga sebaliknya semakin kecil/rendah risk-taking dalam sebuah bank, kemungkinan deviden yang akan didapatkan semakin tinggi. Karena dalam risk-taking yang tinggi, bank lebih memilih untuk menahan labanya dan tidak membagikan dividen. Kemungkinan yang terjadi yaitu bank memanfaatkan laba tersebut untuk menjaga kecukupan modal.

Hubungan negatif juga dimungkinkan terjadi karena adanya ketaatan Bank pada Undang-Undang (peraturan) perbankan yang tidak melakukan prilaku yang menyimpang (Moral Hazard) melalui mekanisme pengalihan resiko (risk shifting) dalam melakukan pembayaran deviden. Hal ini disebabkan karena bank takut untuk melanggar Undang-Undang, sehingga bank lebih memilih untuk menjaga kecukupan modal bank.

Dengan demikian dapat disimpulkan bahwa di Indonesia tidak terjadi moral hazard yang dilakukan melalui mekanisme pengalihan resiko (risk shifting) dari manajer dan pemegang saham kepada deposan, pemberi pinjaman, dan lembaga pemberi pinjaman (LPS) dalam bentuk pembagian deviden.

\section{Pengaruh Free Cash Flow (X2) terhadap Pembagian Deviden}

Nilai $t_{\text {hitung }}$ dari X2 sebesar 2.129 dengan nilai signifikannya adalah 0.040 , sementara nilai $\mathrm{t}_{\text {tabel }}$ pada $\alpha=0.05$ diperoleh nilai sebesar 2.02809 artinya $t_{\text {hitung }}$ $>\mathrm{t}_{\text {tabel. }}$. Maka keputusannya menerima $\mathrm{H}_{2}$, yang artinya secara parsial $\mathrm{X} 2$ berpengaruh secara signifikan terhadap Y, dan memiliki hubungan yang positif, dimana semakin tinggi free cash flow dalam sebuah perusahaan/bank semakin tinggi deviden yang akan dibagikan, begitu juga sebaliknya semakin rendah free cash flow dalam sebuah perusahaan/bank, semakin rendah pula deviden yang akan dibagikan. Hal ini berarti semakin besar free cash flow yang tersedia dalam suatu perusahaan, maka dapat dikatakan semakin sehat perusahaan tersebut karena memiliki kas yang tersedia untuk pembayaran hutang dan pembayaran kepada pemegang saham dalam bentuk deviden.

\section{Uji Statistik F (Simultan)}

Pengujian ini dilakukan untuk menunjukkan apakah semua variabel independen atau bebas yang dimasukkan model mempunyai pengaruh secara bersama-sama terhadap variabel dependen/terikat.. Berdasarkan hasil uji F,

diperoleh nilai $\mathrm{F}$ hitung sebesar 5.969 dan nilai probabilitas sebesar 0,006. Nilai $F_{\text {hitung }}>F_{\text {tabel }}$ yaitu $5.969>3.2594$ karena sig lebih kecil dari pada nilai alpha 0,05 , maka model regresi dapat digunakan untuk memprediksi Probability (Y) atau dapat dikatakan bahwa X1 dan X2 secara bersama-sama (simultan) berpengaruh terhadap Y.

Dengan semakin rendahnya risk-taking dalam sebuah perusahaan, semakin tinggi pula kemungkinan aliran kas yang masuk ke bank atau aliran kas yang tersedia untuk dibagikan kepada para pemegang saham atau pemilik dalam bentuk deviden, karena perusahaan dengan capaian laba yang lebih tinggi akan memiliki motivasi lebih untuk membagi deviden. Perusahaan dengan aliran kas bebas berlebih juga akan memiliki kinerja yang lebih baik dibandingkan perusahaan lainnya karena mereka dapat memperoleh keuntungan atas berbagai kesempatan yang mungkin tidak dapat diperoleh perusahaan lain.

Berdasarkan penjelasan diatas, maka dapat disimpulkan bahwa, dalam risk taking yang tinggi bank lebih memilih untuk menahan labanya atau tidak membagikan deviden, karena bank memanfaatkan laba tersebut untuk menjaga kecukupan modal bank, dan ketaatan bank pada Undang-Undang yang tidak melakukan prilaku yang menyimpang (moral hazard) melalui mekanisme pengalihan resiko (risk shifting) dalam melakukan pembayaran deviden. Akan tetapi apabila perusahaan memiliki free cash flow atau aliran kas yang berlebih, perusahaan lebih baik membaginya dalam bentuk pembagian dividen, karena untuk mengurangi kemungkinan dana tersebut diboroskan pada proyek yang tidak menguntungkan. Bagi perusahaan yang melakukan pengeluaran modal atau pembagian deviden kepada pemegang saham, free cash flow akan mencerminkan dengan jelas mengenai perusahaan manakah yang masih mempunyai kemampuan di masa depan dan yang tidak, sehingga dengan demikian akan mempengaruhi keputusan para investor. Dimana Seperti yang kita ketahui bahwa investor cenderung mengharapkan pembayaran deviden yang stabil, karena dapat mengurangi resiko ketidakpastian pada saham yang ditanamkannya. Stabilitas deviden juga akan meningkatkan kepercayaan investor untuk tetap menanamkan modalnya di perusahaan tersebut. 


\section{PENUTUP}

\section{Kesimpulan}

Berdasarkan hasil penelitian dan pembahasan dapat disimpulkan :

1. Risk Taking berpengaruh signifikan terhadap pembagian deviden pada bank umum yang terdaftar di Bursa Efek Indonesia (BEI) tahun 2014-2016.

2. Free cash flow berpengaruh signifikan terhadap pembagian deviden pada bank umum yang terdaftar di Bursa Efek Indonesia (BEI) tahun 2014-2016.

3. Risk taking dan free cash flow secara bersamasama (simultan) berpengaruh terhadap pembagian deviden pada bank umum yang terdaftar di Bursa Efek Indonesia (BEI) tahun 2014-2016.

\section{Saran}

1. Bagi praktisi, khususnya manajemen perusahaan, hasil penelitian ini diharapkan dapat menjadi bahan pertimbangan dalam keputusan kebijakan divident payout ratio, serta bila profitablitas meningkat, maka sebaiknya dividen yang dibayarkan pada pemegang saham juga ditingkatkan, karena dengan profitabilitas yang meningkat seharusnya kemampuan perusahaan untuk membayar deviden makin tinggi.

2. Bagi investor, hasil penelitian ini diharapkan dapat memberikan informasi tambahan mengenai perusahaan yang memberikan keputusan kebijakan pembagian deviden, sehingga investor dapat lebih berhati-hati dalam melakukan penilaian terhadap perusahaan yang dipilih untuk berinvestasi.

3. Bagi peneliti selanjutnya, menambah beberapa variabel independen yang mungkin berpengaruh terhadap dividend payout ratio, serta memperluas populasi pada keseluruhan perusahaan publik di indonesia dalam waktu pengamatan yang lebih lama, sehingga nantinya diperoleh hasil yang dapat lebih digeneralisasikan.

\section{KEPUSTAKAAN}

Adnan, Muhammad Akhyar, dkk (2012). Pengaruh Profitabilitas, Leverage, Growth, Dan Free Cash Flow Terhadap Dividend Payout Ratio Perusahaan Dengan Mempertimbangkan Corporate Governance Sebagai Variabel
Intervening. Jurnal Akuntansi Univeristas Muhammadiyah Yogyakarta

Aristantia,Dwi dan I Made PDW (2014). Investment Opportunity Set Dan Free Cash Flow Pada Tingkat Pembayaran Dividen Perusahaan Manufaktur. Jurnal Akuntansi Universitas Udayana (Unud), Bali, Indonesia

Brigham, Eugene F. Dan Joel F. Houston. (2001). Manajemen Keuangan, Edisi 8. Jakarta: Erlangga.

Djojosoedarso, Soeisno. 2003. Prinsip - Prinsip Manajemen Risiko Asuransi. Jakarta : Penerbit Salemba Empat

Ghozali. (2011). Aplikasi Analisis Muktivariate Dengan Program IBM SPSS 19 (Edisi Kelima). Semarang:Universitas Dipenogoro.

(2006). Aplikasi Analisis Multivariate dengan Program SPSS. Semarang: Badan Penerbit Universitas Diponegoro.

Hanafi, M. Dan Mamduh. (2011). Manajemen Keuangan, Edisi 1.Yogyakarta: BPFE

Harmono. (2014). Manjemen Keuangan, Berbasis Balance Scorecard Pendekatan Teori, Kasus dan Riset Bisnis. Edisi 1. Jakarta: Bumi Aksara.

Haryadi, Lias Dwi (2014). Pengaruh Agency Cost, Profitability, Dan Free Cash Flow Terhadap Dividend Payout Ratio Pada Perusahaan Manufaktur Yang Terdaftar Di Bursa Efek Indonesia. Jurnal Akuntansi Fakultas Ekonomi Universitas Negeri Yogyakarta.

Hellstrom G.Inagambaev (2012). Determinan of Dividend Payout Ratio. a Study of Swedish Large and Medium. UMEA University Sweden.

Ibrahim, Taswan dan Ragimun (2010). Moral Hazard dan Pencegahannya Pada Industri Perbankan Di Indonesia. Jurnal Ekonomi Makro FEB Universitas Gajah Mada.

Ikatan Akuntan Indonesia (2013). Pernyataan Standar Akuntansi Keuangan. Jakarta: Salemba Empat. 
Ikhsan, Arfan., dkk (2014). Metodologi Penelitian Bisnis, Edisi pertama. Bandung: Citapustaka Media.

Iryuliawati (2013). Pengaruh Free Cash Flow Terhadap Dividend Policy Pada Perusahaan Lq45 Di Indonesia. Jurnal fakultas Ilmu sosial dan Ilmu politik Universitas Lampung.

Ismail (2011). Akuntansi Bank, Teori dan Aplikasi dalam Rupiah. Edisi Pertama. Jakarta: Kencana

Kinanti, Regina Galuh. (2015). Pengaruh RiskTaking Terhadap Pembagian Deviden (Studi Empiris Pada Bank Umum yang Terdaftar Di BEI Tahun 2004-2013). Jurnal Akuntansi Studi Akuntansi Fakultas Ekonomi Universitas Atma Jaya Yogyakarta.

Kuncoro, M. (2009), Metode Riset Untuk Bisnis dan Ekonomi, Edisi ketiga, Jakarta: Erlangga

Lucyanda, Jurica dan Lilyana. (2012). Pengaruh Free Cash Flow dan Struktur Kepemilikan Terhadap Divident Payout Ratio. Jurnal Akuntansi Universitas Bakrie, Jakarta.

Mulyaningsih, Ratnasari. (2015). Pengaruh Profitabilitas, Free Cash Flow, Investment Opportunity Set, Dan Risiko Terhadap Kebijakan Dividen. Jurnal. Universitas Muhammadiyah Yogyakarta

Mulyawan, Setia. (2015). Manajemen Keuangan. Bandung: Pustaka Setia.

Onali, Enrico (2009). Dividends and Risk in European Banks. Bangor University. United Kingdom.

Pradana, S.W.L (2016). Dampak Profitabilitas, Aliran Kas Bebas, Dan Kesempatan Investasi Terhadap Pembayaran Dividen Perusahaan Perbankan. Jurnal Keuangan dan Perbankan Fakultas Ekonomi Universitas Atma Jaya Yogyakarta.

Prasetyo, Djoko Adi dan Bambang Suryono (2015). Pengaruh Profitabilitas, Free Cash Flow,
Investment Opportunity Set Terhadap Divident Payout Ratio. Jurnal Akuntansi Sekolah Tinggi Ilmu Ekonomi Indonesia (STIESIA) Surabaya.

Ramadhan,Wiby Aqlia (2014). Pengaruh Free Cash Flow, Investment Opportunity Set, Dan Sales Growth Terhadap Dividend Policy Pada Perusahaan Manufaktur Yang Terdaftar Di Bursa Efek Indonesia.

Jurnal Manajemen Universitas Negeri Yogyakarta.

Rosdini, Dini (2005). Pengaruh Free Cash Flow Terhadap Divident Policy. Jurnal Akuntansi

Saputro W.H.A (2016). Pengaruh Profitabilitas, Free Cash Flow, Investment Opportunity Set Dan Leverage Terhadap Divident Payout Ratio (Study Empiris Pada Perusahaan Bumn Yang Terdaftar Di Bursa Efek Indonesia Tahun 2011-2015). Jurnal Akuntansi.

Sekaran, Uma. 2003. Research Method for Business: A Skill Building Approach. John Wiley \& Sons, Inc.

Scott, William R (2012). Finanial Acoounting Theory. Edisi 6. Prentice hall. United States of America.

Siregar, B (2007). Ekspropriasi Pemegang Saham Minoritas dalam Struktur Kepemilikan Ultimat. Simposium Nasional Akuntansi X. Unhas. Makassar.

Sugiono. (2010). Metode Penelitian Bisnis. Cetakan kesebelas, Bandung: Alfabeta

Undang-undang RI Nomor 7 tahun 1992 tentang perbankan sebagaimana diperbaharui dengan UU nomor 10 tahun 1998.

Yunior, Andreas Sunarto Tjitrahadi (2015) Pengaruh Free Cash Flow Terhadap Divident Payout Ratio Pada Perusahaan Manufaktur yang Terdaftar Di Bursa Efek Indonesia Periode Tahun 2001-2007. Jurnal Akuntansi Fakultas Ekonomi Univesitas Atma Jaya Yogyakarta. 


\section{Sumber Internet :}

https://www.sahamok.com/emiten/sekt

or-keuangan/sub-sektorbank/

http://www.ojk.go.id/id/kanal/perbanka

n/Pages/Bank-Umum.aspx

website Bursa Efek Indonesia

(http://www.idx.co.id/). 